\title{
Non-native english speaking elementary ELL teachers' culturally responsive leadership profile in an ESL context *
}

\author{
Perfil de liderazgo y sensibilidad cultural de maestros no \\ nativos de ingles de primaria en un contexto de ingles \\ como segunda lengua
}

\author{
Valentin Ekiaka Nzai, \\ Patricia Gómez, Concepción Reyna, \\ Kang-Fan Jen \\ Assistant Professor \& Graduate Coordinator (M.S. in Bilingual Education) \\ Texas A\&M University - Kingsville Kingsville, TX, USA \\ E-mail: kuve2002@tamuk.edu \\ patricia.Gomez@tamuk.edu \\ reynaeric03@yahoo.com \\ jengunfan@hotmail.com
}

Received: 27 - Apr - 12 / Accepted: 26 - Sep -12

Abstract

Culturally responsive instruction has been suggested as quality education (Edwards, 2003) for minority students in subtractive and additive bilingualism settings. However, analytical curriculum development of several official English programs revealed that the gender-centric (malecentric) and Ethno-centric (Euro/Western-centric) approaches were deeply embedded in most English textbooks of curriculum development. The intent of partial mixed methods paper consisted of exploring some non-native English speaking teachers English teachers' culturally responsive leadership profile in order to further the discussion on not only how to promote English curriculum transformation in English as second language (ESL) and English as foreign language (EFL) settings, but also to effectively train culturally responsive non-native English speaking (NNES) English pre-service teachers. Comparative data analysis suggested that there were no causal relationship between NNES English teachers' culturally responsive leadership styles and their abilities to perform multicultural transformation of English curriculums. To be highly effective in transforming English curriculum, NNES English teachers needed to be systematically trained on how to do so. Implications for NNES English pre-service teacher education are framed from the culturally responsive and anti-oppressive education approaches.

Keywords: culturally responsive leadership styles, multicultural curriculum transformation, non-native English speaking English teachers, gender/male-centric and Ethno/Euro \& Western-centric.

\section{Resumen}

La enseñanza culturalmente sensible ha sido sugerido como una educación de calidad (Edwards, 2003) para los estudiantes cultural y lingüísticamente diversos en los Estados Unidos de América. Análisis de varios programas de estudio de aprendizaje del Inglés (ELL), reveló que los enfoques sexo-céntrico (masculino-céntrico) y etno-céntrico (Euro/Western-céntrico) estaban profundamente arraigados en la mayoría de los libros de texto. La intención de este documento parcial de métodos mixtos consistió en explorar algunos hablantes de Inglés no nativos (NNES) perfil de los maestros de primaria ELL liderazgo culturalmente sensible con el fin de fomentar el debate sobre la forma de promover la transformación curricular multicultural en las aulas de primaria y cómo efectivamente formar culturalmente a los profesores de pre-servicio NNES y básico ELL en un contexto específico ESL. Análisis comparativo de datos sugirieron que no había relación causal entre los estilos de liderazgo de los participantes con sensibilidad cultural y su capacidad para llevar a cabo la transformación curricular multicultural. 
Las implicaciones para los profesores NNES y básico ELL pre-servicio en formación de los profesores se enmarcan desde la enseñanza culturalmente sensible y enfoques multiculturales de transformación curricular.

Palabras Claves: Instrucción culturalmente sensible, transformación currículo multicultural, estudiantes básicos ELL, Profesores NNES ELL.

\section{Résumé}

L'enseignement culturellement sensible a été perçu comme une éducation de qualité (Edwards, 2003) pour les étudiants culturellement et linguistiquement divers dans les États-Unis d'Amérique. L'analyse de plusieurs plans d'études de l'apprentissage de l'anglais (ELL) a montré que les approches sexiste et ethnocentriste (euro-centriste) étaient profondément enracinés dans la plupart des livres de texte. L'intention de ce document partiel de méthodes mixtes a été d'explorer quelques locuteurs de l'anglais dont la langue maternelle était une autre (NNES), le profil des instituteurs de primaire ELL, le leadership culturellement sensible, afin d'ouvrir le débat sur la manière de promouvoir la transformation curriculaire multiculturelle dans les salles de classe de primaire et comment former culturellement les enseignants stagiaires NNES et les instituteurs ELL dans un contexte spécifique ESL. L'analyse comparative des données a montré qu'il n y y avait un rapport causal entre les styles de leadership des participants culturellement sensibles et leur capacité pour être à l'origine d'une transformation curriculaire multiculturelle. Les implications pour la formation des instituteurs NNES et stagiaires ELL sont délimitées à partir de l'enseignement culturellement sensible et les approches multiculturelles de la transformation curriculaire.

Mots clés: Formation culturellement sensible, transformation curriculaire multiculturelle, étudiants de primaire ELL, Instituteurs NNES ELL.

\section{Resumo}

O ensino culturalmente sensível foi sugerido como uma educação de qualidade (Edwards, 2003) para os estudantes cultural e linguisticamente diversos nos Estados Unidos da América. Análise de vários programas de estudo de aprendizagem do Inglês (ELL), revelou que os enfoques sexocêntrico (masculino-cêntrico) e etnocêntrico (Euro/Western-cêntrico) estavam profundamente enraizados na maioria dos livros de texto. A intenção deste documento parcial de métodos mistos, consistiu em explorar alguns falantes de Inglês não nativos (NNES) perfil dos professores de primária ELL liderança culturalmente sensível com o fim de fomentar o debate sobre a forma de promover a transformação curricular multicultural nas salas de aula de primária e como efetivamente formar culturalmente os professores de préserviço NNES e básico ELL em um contexto específico ESL. Análise comparativa de dados sugeriram que não havia relação causal entre os estilos de liderança dos participantes com sensibilidade cultural e sua capacidade para realizar a transformação curricular multicultural. As implicações para os professores NNES e básico ELL pré-serviço em formação dos professores se desde o ensino culturalmente sensível e enfoques multiculturais de transformação curricular.

Palavras Chaves: Instrução culturalmente sensível, transformação currículo multicultural, estudantes básicos ELL, Professores NNES ELL.

* The research project about "Non-Native English Speaking Elementary ELL Teachers' Comparative advantages" was carried out at Texas AEM University-Kingsville E University of Nebraska- Lincoln in the Bilingual Education Program. 


\section{Introduction}

Culturally responsive instruction, a pedagogical approach that recognizes the importance of including students' cultural references in all aspects of learning (Banks, 2008; Gay, 2002; Ladson-Billings, 1995) has been suggested as quality education (Edwards, 2003) for culturally and linguistically diverse students in the United States of America (USA). However, documental analysis of several elementary schools English Language learning (ELL) curriculums in USA suggested that the most of them are male-centric and Euro/Westerncentric, which might implicitly or explicitly yield to teaching ELL classrooms from a subtractive bilingualism approach (see next paragraph). The gender - centric $\mathcal{E}$ ethno-centric viewpoints are apparent in many school textbooks in USA (Spring, 2007).

In the United States of America, teaching ELL classrooms from a subtractive bilingualism approach means mainstreaming ELL students in order to help them become monolingual in English quickly (Soltero, 2004). In other words, ELL's heritage languages and cultures are not reflected in the ELL curriculums. According to some scholars (Banks, 2008; Haberman, 1986), failure to implement culturally responsive instruction within elementary ELL classrooms (also called bilingual classrooms in some southern states) is due to teachers' inability to effectively apply the basic principles of responsive pedagogy (Banks, 1993; Gay, 2002; LadsonBillings, 1995; McIntosh, 2000).

In other words, NES and NNES elementary English ELL learning teachers cannot effectively implement quality teaching when instructing elementary English learners if they lack the basic culturally responsive skills. Traditionally, in elementary ELL classrooms, ELL teachers do not only teach English to students from culturally and linguistically different backgrounds (those who do not speak English at home). They also teach ELL students other content-areas such as mathematics, science and social sciences. (Baker, 2011; Rothenberg \& Fisher, 2009; Soltero, 2004)

In reality, becoming a highly culturally responsive elementary ELL teacher is a long and arduous intercultural learning process which requires a lot of investment. In multicultural settings, argued Canagarajah (1999, 2007), NNES teachers might be highly effective because they should naturally develop the needed cultural, linguistic and leadership skills to be able to teach from the cultural-match and culturally responsive approaches. However, the commonly accepted view deeply embedded in many school districts and educational institutions has been that NNES ELL teachers are second in knowledge and performance to native speaking (NES) ELL teachers. The authority of NES ELL teachers is accepted as the norm regardless of their lack of cultural responsiveness skills (Canagarajah, 1999, 2007; Howard, 2006).

In the United States of America, especially in the state of Nebraska, the English language learners' population is rapidly increasing. So far, Nebraska is among 13 states with at least 200\% growth in English Language Learners population between 2000-2005 (Nebraska State Paper, 2009). So, teaching from the cultural-match postulate (Banks, 2010; Gay, 2002; LadsonBillings, 1994; Middleton, et al., 1988) suggested the importance of increasing NNES (also called bilingual) teachers' representation in the corps of elementary teachers, as they will serve as role models for current and future elementary English language learners. A claim (Banks, 1998, 2008; Braine, 1999; Braine E Ling, 2007; Canagarajah, 1999, 2007; Gay, 2002; Haberman, 1986; Ladson-Billings, 1994; Llurda, 2005 reference erased) has been made that NNES teachers 
possess the required cultural competence to assure culturally responsive instruction within English language classrooms, especially in pluralistic and multicultural settings. However, a relaively low number of scholars in ELL and bilingual education fields in the USA (Ekiaka $\varepsilon$ Reeves, 2010) have looked at the basic profile of culturally responsive NNES elementary ELL teachers in an ESL context.

The intent of this paper consists of exploring some NNES or bilingual elementary teachers' culturally responsive leadership profiles in a predominantly subtractive bilingualism setting, in order to further the discussion on how to effectively train culturally responsive NNES or bilingual pre-service teachers in an ESL context using a partial mixed methods approach (further details in the methodology section). To do so, the following two questions should be answered:

a) In a subtractive bilingualism setting, how do NNES elementary ELL teachers implement culturally responsive teaching tenets and principles when teaching elementary ELL classrooms (English, mathematics, science and social sciences)?,

b) What are the optimal culturally responsive leadership profiles which helped research participants to perform ELL curriculum transformations in a predominantly subtractive bilingual setting?

At this stage of the research, culturally responsive leadership means not only the ability to perform elementary ELL classrooms' curriculum transformation, but also to inspire elementary ELL students to become familiar with both cultures (heritage and host) through charisma, individual consideration and role-modeling.

Certainly, the answers to the aforementioned questions will evoke professional awareness, spark interest, stimulate thought, and disseminate information, knowledge and skills needed to prepare culturally responsive elementary ELL teachers. They also might assist in the design of interdisciplinary experimental research projects in culturally responsive elementary ELL teacher education plans in an ESL context.

To help our readers understand the structure of this research report, the next section provides a brief theoretical overview of culturally responsive curriculum transformation and leadership types before offering a broader description of research subjects and methodology. The presentation of findings, conclusions and implications for elementary ELL teacher education in an ESL context will immediately follow.

\section{Brief Overview of Culturally Responsive Teaching; Multicultural Curriculum Transformation \& Leadership Types}

In pluralistic and multicultural settings, culturally responsive teaching is an emerging topic that calls the attention of many scholars. The foundational idea of culturally responsive teaching is that responding to diverse ELL's needs requires that educators actively, collaboratively, and consistently discuss and investigate multiple human perspectives, while considering their impact on educational experiences (Gay, 2002). Culturally responsive instruction encompasses anti-oppressive visions of teaching culturally and linguistically diverse students (Kumashiro, 2004 $\varepsilon$ 2007) It is based on two principles: the ethic of care (Nodding, 1999) - every human being matters and deserves the right to be heard and respected - and the ethic of fair teaching: every student ought to have access to fair teaching and curriculum that reflect his living realities. Each student should have the opportunity to tell his/ her own story, to teach and learn from others.

Following from the above, teaching elementary ELL classrooms should be viewed 
as a contextual and developmental process. In multiculturalism settings, argued Canagarajah $(1999,2007)$, culturally responsive practices are most effective when prior experiences, cultural backgrounds and ethnic identities of teachers and students are included in its implementation. Historically, elementary ELL students in USA have been taught from the Eurocentric and/ or Western-centric frameworks that legitimated ELL students' acquired identities while devaluing their heritage languages and cultures. According to Spring (2007), teaching elementary ELL classrooms from Eurocentric and/or Westerncentric perspective means promoting implicit and/or explicit negation of heritage languages and cultures.

This situation is quite visible in predominantly subtractive bilingualism settings, where elementary ELL teachers, especially Native English Speakers (NES) and some NNES as well, continue to ignore, impugn, and silence the cultural orientations, values, and performance styles of elementary ELL students through imposition of mainstream's cultural hegemony, while denigrating their heritage languages and cultures (Gay, 2000; Kumashiro,2004 \& 2007). Fostering culturally responsive practices for elementary ELL classrooms suggests building a cultural continuity when educating them. Hence, it is incumbent upon ELL teachers, ELL teacher educators, ELL educational managers and policymakers to be congruent in applying the basic culturally responsive pedagogy principles for elementary ELL classrooms in the United States of America.

In other words, teaching elementary ELL classrooms through culturally responsive pedagogy means recognizing, respecting, and using students' identities and backgrounds as meaningful sources (Nieto $\&$ Bode, 2008) for creating optimal ELL environments. Moreover, Ladson-Billings (1995) explains that culturally responsive teachers teach the whole child. Along with the academic achievement improvement, classroom input should help students to maintain their identities while developing a sense of community and acquiring an ethic of success. Expectations and skills should not be taught as separate entities but rather woven together into an integrated whole that permeates the curriculum content and the entire modus operandi of the classroom.

Its multidimensional aspects mean that culturally responsive teaching encompasses curriculum content, learning context, classroom climate, student-teacher relationships, instructional techniques, and performance assessments. A team-oriented teaching is sometimes required to tap into a wide range of cultural knowledge, experiences, contributions, and perspectives. Emotions, beliefs, values, ethos, opinions, and feelings are scrutinized along with factual information to make curriculum and instruction more reflective of a responsive ethnic diversity. Priority should be given to those cultural aspects that mostly directly affect learning (Gay, 2000, 2002).

By doing so, the teaching input helps the learning community clarify their ethnic values while correcting factual errors about cultural heritages of the classroom's members. In the process of accomplishing these goals, students are held accountable for knowing, thinking, questioning, analyzing, feeling, reflecting, sharing and acting (Gay, 2000). It is unrealistic to expect a NNES ELL teacher, even with higher cultural competence development, to move directly from a highly mainstream-centric, Euro or Western-centric ELL curriculum to one that focuses on decision making or social action and personal culturally responsive curriculum design. Reshaping a mainstream-centric curriculum, Euro or Western-centric comprises several levels of expertise to be learned by culturally responsive elementary ELL teachers. 
The above assumption led Banks (1993) and McIntosh (2000) to identify five levels in reshaping a formal mainstream-centric curriculum. A curriculum's transformation approach ranges from slight modifications to a fully-revised social awareness and action conceptualizations. Banks (1993) and McIntosh (2000) have formulated continuums for curricular reform that help move transformation efforts from the former toward the latter. Here, we followed Banks (1993) and McIntosh's (2000) conceptualization of multicultural curriculum transformation.

In fact, transforming a mainstream curriculum means making it culturally responsive to the background of students. Reshaping a mainstream curriculum requires that the changes challenge students to develop higher-order knowledge and skills (Villegas, 1991). Ismat Abdal-Haqq (1994) agreed that a curriculum that is culturally responsive capitalizes on students' cultural backgrounds rather than attempting to override or negate them.

Some studies (Scherer, 1999, 1992; Spears, Oliver, E Maes, 1990; Banks, 2001; Chion-Kenny, 1994; Dickerson, 1993; Villegas, 1991; Hilliard, 1991, 1992; Gay, 2000) on culturally responsive curriculum highlight that an effective culturally responsive curriculum:

a) is integrated and interdisciplinary

b) is meaningful, student centered, and connected to the child's real life

c) develops higher-order knowledge and skills

d) utilizes a variety of learning strategies, such as cooperative learning, whole language, and diverse learning styles.

In fact, it is difficult for novice elementary ELL teachers to learn how to transform a Western-centric ELL curriculum into a culturally responsive one. It requires a considerable knowledge base of cultural diversity. The starting point of curriculum transformation is the curriculum of the mainstream classroom, the first formal plan of instruction approved by the policy and governing bodies of educational systems. Banks (1993) and McIntosh (2000) suggested that many mainstream curriculums in the USA are Eurocentric and male-centric. They fully ignore the experiences, voices, contributions, and perspectives of non-dominant individuals and groups in all subject areas. All educational materials, including textbooks, films, and other teaching and learning tools present information in a purely Eurocentric, male-centric format. This level of curriculum design is also called the Contribution Stage.

This stage is harmful for both students who identify with mainstream culture as well as individuals from non-dominant groups. It has negative consequences for the former because it reinforces their false sense of superiority, gives them a misleading conception of their relationship with other racial and ethnic groups, and denies them the opportunity to benefit from the knowledge, perspectives, and frames of reference that can be gained from studying and experiencing other cultures and groups (Banks 1998). The curriculum of the mainstream has negative consequences for students from nondominant groups by failing to validate their cultures, experiences, and perspectives. It further alienates students who already struggle to survive in a school culture that differs so greatly from their home cultures (Banks, 1998). Moreover, diverse student cultures are viewed as a corruption of the dominant culture (Koppelman, 2008, Gruwell, 2007).

Given the increasing diversity in schools, culturally responsive ELL teachers used the symbolic curriculum (Gay, 2000) to promote diversity within the classrooms. At the Additive Stage (also called the Heroes and Holidays Stage), teachers promote celebration of differences by integrating information or resources about famous 
people and the cultural artifacts of various groups into the mainstream curriculum. Bulletin boards may contain pictures of heroes and teachers may plan special celebrations for Black History Month, Women's History Month, Hispanic and Asian Heritage Months, etc. Learning about other cultures focuses on costumes, foods, music, images, symbols, icons, mottoes, awards and other tangible cultural artifacts.

Culturally responsive teachers are critically conscious of the power of the symbolic curriculum as an instrument of teaching and use it to help to convey important information, values, and actions about ethnic and cultural diversity. The strengths of this stage are that the teacher is attempting to diversify the curriculum by providing materials and knowledge outside the mainstream culture and that the Heroes and Holidays approach is fairly easy to implement with little new knowledge needed by the teacher. Still, the weaknesses heavily outweigh the strengths: by focusing celebratory attention on non-dominant groups outside the context of the rest of the curriculum, the teacher is further defining these groups as the others; curriculums at this stage fail to address the real experiences of non-dominant groups, instead focusing on the accomplishments of a few heroic characters. As a result, students may learn to consider the struggles of non-dominant groups as extra-information instead of important knowledge in their overall understanding of the world. The special celebrations at this stage are often used for justification not to truly transform the curriculum. As such, the Heroes and Holidays approach trivializes the overall experiences, contributions, struggles, and voices of non-dominant groups, fitting directly into a Eurocentric, male-centric curriculum.

The third level of Banks and McIntosh's (2000) curriculum transformation is called the Integration or Transformative Stage. In this stage, teachers move beyond heroes and holidays to add substantial materials and knowledge about nondominant groups to the curriculum. The teacher may add to her or his collection of books those by minority and women authors. The strengths of the Integration Stage are that it moves beyond special celebrations to deal with real issues and concepts and that it more closely ties the new material into the rest of the curriculum. But many weaknesses remain: the curriculum design is still teacher-oriented, new materials and units become secondary resources, knowledge as textbooks and the meat of the curriculum are still based on a Eurocentric, male-centric orientation (Banks, 1993 and McIntosh, 2000), and new information is still delivered from a Eurocentric, male-centric perspective.

The fourth level of curriculum transformation is named Structural Reform. At this stage, new materials, perspectives, and voices are interwoven seamlessly with current frameworks of knowledge to provide new levels of understanding from a more complete and accurate curriculum. The teacher dedicates herself or himself to continuously expanding her or his knowledge base through the exploration of various sources from various perspectives, and by sharing that knowledge with her or his students. Students learn to view events, concepts, and facts through various lenses. For example, the American History curriculum includes African American History, Women's History, Asian American History, Latino American History, and all other previously differentiated fields of knowledge.

The last level of curriculum transformation, in this case elementary ELL curriculum, is a continuum of previous stages. The Social Action Stage takes the changes made in the structural reform a stage further. Important social issues including racism, sexism, discrimination and classism are directly addressed in the curriculum. The voices, ideas, and perspectives of the students' cultures are brought to the fore in the learning experience - the students themselves become yet another diversity classroom resource. 
The textbook is viewed as a single perspective among many, and the relevance of its limitations, along with those of other educational media, are explored and discussed. At this point, the reshaped curriculum is an attempt to capitalize students' cultural backgrounds rather than attempting to override or negate them (AbdalHaqq, 1994).

An additional feature of effective responsive teaching practices consists of displaying appropriated leadership styles. Research (Bass E Riggio, 2006; Bartunek, 1986; Greanleaf, 2002) on leadership styles highlighted three leadership styles. The Transactional Leadership Style attempts to maintain the status quo and strives for perfection at one's job. Teachers create strong expectations with students, along with clear indications of what students will get in return for meeting these expectations. Teacher leadership actions are linked to a reward system. The Transformational Leadership Style is highlighted by: intellectual stimulation, individualized consideration, and inspirational motivation. Teachers build trust, admiration, loyalty, and respect among students.

Becoming a role model for the students is highly important by the teacher who expects his/her students to achieve their maximum performance in order to become highly competitive in the current global world. The Servant Leadership Style, according to Greenleaf (2002), assumes that the leader is servant first. In this case, it begins with the natural feeling that the teacher wants to serve his/her students. Undoubtedly, the above framework is very important to understand the dynamic of this research report. The next segment briefly discusses the research methodology.

\section{Methodology}

As suggested above, the intent of this paper consisted of exploring some NNES elementary teachers' culturally responsive leadership profiles in a north-central state of the United States of America, in order to further the discussion on how to effectively train culturally responsive NNES or bilingual pre-service teachers. Participants were 6 in-service non-native English-speaking elementary ELL teachers available in the targeted school district. They ranked themselves as effective teachers of diverse classrooms. Two participants considered themselves as multilingual, multicultural individuals (Spanish/ Paraguay-Guarani/Paraguay-Portuguese/BrazilEnglish/USA and Spanish/Mexico-Portuguese/ Brazil-French/France-English/USA) while others were ranked as bilingual-bicultural ones (Spanish/Mexico-English/USA). None of them were working in dual-language programs.

This study used a partial mixed methods research (MMR) design following Leech and Onwuegbuzie's (2007) mixed methods research typology. It is important to clarify that mixed methods research, according to Onwuegbuzie and Johnson (2004), falls on a continuum from not mixed (or mono-method designs) to fully mixed methods, with partially mixed designs occupying regions somewhere between monomethod designs and fully mixed method designs. Specifically, mono-methods involve the exclusive use of either quantitative or qualitative research techniques in a study. Once a study combines quantitative and qualitative techniques to any degree, the study no longer can be viewed as utilizing a mono-method design. At this stage, the research is using a partially mixed design (Leech and Onwuegbuzie, 2007). Therefore, the research design of this project fell under partial MMR typology.

Although the grounded theory (Charmaz, 2010; Creswell, 2012) approach is the central research strategy of this research project, the authors deliberately used one questionnaire (a quantitative - QUANT- data collection tool) to support qualitative data analysis. Given the low 
number of participants, we limited the QUANT data analysis to a graphical representation only excluding further descriptive statistical analysis. QUAL data were gathered through in-depth interviews and field observations.

From the grounded theory (Charmaz, 2010; Creswell, 2012) approach, identification of the hypothetical observation is required for data analysis. Based on exploratory field visits which took place while designing this research proposal, we contended that culturally responsive leadership should be the hypothetical central observation phenomenon. Therefore, the research questions we were exploring could be stated as follow:

a) In a subtractive bilingualism setting, how NNES elementary ELL teachers implement culturally responsive teaching tenets and principles when teaching elementary ELL classrooms (English, mathematics, science and social sciences)?, and

b) What is the optimal culturally-responsive leadership profile(s) which helped research participants to perform ELL curriculums' transformation in a predominantly subtractive bilingual setting?

Unlike random sampling, purposeful sampling allows the researchers to choose participants that have in-depth knowledge of the subject at hand or where information is rich (Patton, 1990). For this research, participants were selected according to the following criteria: a) be in-service bilingual-bicultural or multilingualmulticultural Elementary (from kindergarten to fifth grade) ELL teachers in Lincoln (Nebraska) Public Schools, and b) have a minimum of 3 years of elementary teaching experience in the USA. For the sake of confidentiality and clarity in describing the data, we assigned a pseudonym to each participant. Therefore, the participants will henceforth be referred to as Claudia, Yunka,
Marina, Samantha, Prudencia and Felipe. Research participants had a range of 5-29 years of teaching experiences in USA schools.

Approval for informed consent, which included procedures and protection of human subjects, was obtained from participants. The partial mixed methods QUANT-QUAL (qualitative) data collection strategy was adopted. At first, participants had to fill out a questionnaire with 12 items (See Appendix \#1) related to their orientation to culturally responsive teaching designed by the authors. Based on their answers to the questionnaire, the authors scheduled two initial (90 minutes) classroom observations and one in-depth interview (60 minutes) with each participant. Prior telephone and email contacts took place before scheduling the first meeting.

The questionnaire, called the Orientation to Culturally Responsive Teaching Questionnaire (OCRTQ), was an attempt to provide research participants with an opportunity to reflect on their culturally responsive attitudes, aptitudes, skills, behaviors, etc. to find out if they were conscious of their culturally-responsive leadership competencies and curriculum transformation skills. It was drawn from Gay's (2000 E 2002) characteristics of cultural responsive teaching. These are: orientation to design culturally relevant curricula, orientation to create a caring community of learners, congruity in teaching and cross-cultural communication competencies. Each characteristic of culturallyresponsive teaching was considered as a research variable. Based on the main description of the content of each variable (see chart below), we formulated 4 statements per variable. A total of 12 statements were developed. Research subjects were asked to honestly react to each statement by demonstrating their level of agreement or disagreement with each item. The questionnaire' scale was: strongly agree $=3$, agree $=2$, disagree $=1$, strongly disagree $=0$. 
Orientation to Culturally Responsive Teaching Questionnaire (OCRTQ) Variables Chart

\begin{tabular}{|c|l|l|}
\hline$\#$ & \multicolumn{1}{|c|}{ Variables } & \multicolumn{1}{c|}{ Features } \\
\hline 1 & $\begin{array}{l}\text { Ability to design or prompt culturally } \\
\text { responsive curricula and teaching, to } \\
\text { transform male-centric and Euro or Western- } \\
\text { centric English curriculum }\end{array}$ & $\begin{array}{l}\text { Understanding and use of students' cultural background for teaching purpose; development of } \\
\text { compensatory strategies to overcome cultural and cognitive dissonance within the classroom; } \\
\text { use of culturally responsive protocols of participation in discourse and classroom management, } \\
\text { to learn ethnic home- discipline techniques, etc. classroom management strategies; ability to } \\
\text { determine the multicultural strengths and weaknesses of curriculum and instructional methods, } \\
\text { ability to transform male-centric and/or Euro/Western-centric English curriculum, ability to } \\
\text { develop inclusive social action and personal curriculums. }\end{array}$ \\
\hline 2 & $\begin{array}{l}\text { Capacity to create caring \& nurtured } \\
\text { community of learners and classroom }\end{array}$ & $\begin{array}{l}\text { Passion for others to succeed in life, acceptance of nothing less than high-level success from } \\
\text { students and work diligently to help them accomplish it; care and nurture diverse students, } \\
\text { familiarity with each student reality through home-connection, enhancement of intercultural } \\
\text { servant leadership skills, knowledge of different cultural scaffolding techniques ; behave } \\
\text { in the best interests of others; bind individuals to reference groups, and to other from the } \\
\text { mercy principle and asymmetric approach of human relationships. Use of cultural protocols } \\
\text { of participation in discourse and classroom management, learning ethnic home- discipline } \\
\text { techniques, display of transactional, transformative and servant leadership skills, etc. }\end{array}$ \\
\hline 3 & $\begin{array}{l}\text { Cross-cultural competences } \\
\text { Frequent home-visits to increase cross-cultural competence, understand characteristics of } \\
\text { ethnic communication styles and cultural values, improve teacher-parent connection, etc. }\end{array}$ \\
\hline
\end{tabular}

Since the questionnaire was a new research tool designed by authors, two focus groups, a pilot testing and a peer review process were used to assess its validity prior to formal use. In fact, filling out the questionnaire was the first step of data collection process, which took participants approximately ten minutes to complete. Graphs were used to represent each participant's questionnaire responses for further analysis (see next section). The credibility of the questionnaires' answers was assessed through two initial field visits and classroom observations and one in-depth interview per research subject. Furthermore, data from field, classroom observations and in-depth interview were compared to questionnaires' responses in order to answer the research questions.

Throughout classroom observations, principal investigators paid attention to some research-based indicators of culturally responsive teaching as suggested by Banks (2008) and Gay (2000 \& 2002). The chart above was considered as a classroom observation guide. Classroom observation data were recorded using the traditional paper- and-pencil technique. It helped the principal investigators to verify the validity of participants' responses to the questionnaire. At the end of the second formal classroom observation, an in-depth interview was scheduled with each participant according to the timetable that worked best for him/her during school hours.

The purpose of the initial and follow-up in-depth interviews was to elicit the story of the participants' culturally responsive teacher leadership and curriculum transformation skills. Initially, interviews were scheduled to last 60 minutes. However, given the level of interest from participants, interviews went over 90 minutes per participant. Another 60-minute follow-up faceto-face interview was scheduled two weeks later if there was a need for a deeper exploration and elaboration of crucial ideas. In total, 6 follow-up interviews were conducted (one per participant). All interviews were audiotaped and transcribed by the first author of this paper. Audiotapes were reviewed several times while reading along with 
the transcription in order to assure data accuracy.

Data from the questionnaires was processed using special graphing software (Kaleidagraph 3.5). Data from the interview and classroom observations was reviewed and compared with data from the questionnaire. At that point, themes began to emerge from the data and continued to appear throughout the data analysis process which was conducted using comparative methods. Interviews were transcribed immediately after realisation. Observational field notes were typed and stored in the primary principal investigator's desktop the following day. They were reviewed continually along with the transcribed interview data to come up with the finding themes. The constant comparative method was employed to keep the concepts closely to the data.

Trustworthiness of the research project findings was addressed through a constant data triangulation processes. Data from the questionnaire was compared to classroom observations and in-depth interview responses to ensure data credibility. Also, emerging themes were shared with participants as they arose. The process of research participants checking the research finding themes is essential in assuring that the conclusions were an accurate representation of research participants' responses. Finally, a narrative of findings was written as part of the iterative process of presenting a research report.

\section{Findings}

This segment offers a description of findings. Apparently, the most durable theme which emerged from the analysis of quantitative data suggested that development of culturallyresponsive leadership competencies is an ongoing process. It depends upon not only NNES elementary ELL teachers' level of being familiar with their primary reference culture's heritage and host(s), but also their commitment to transform the official Euro/Western-centric curriculums.

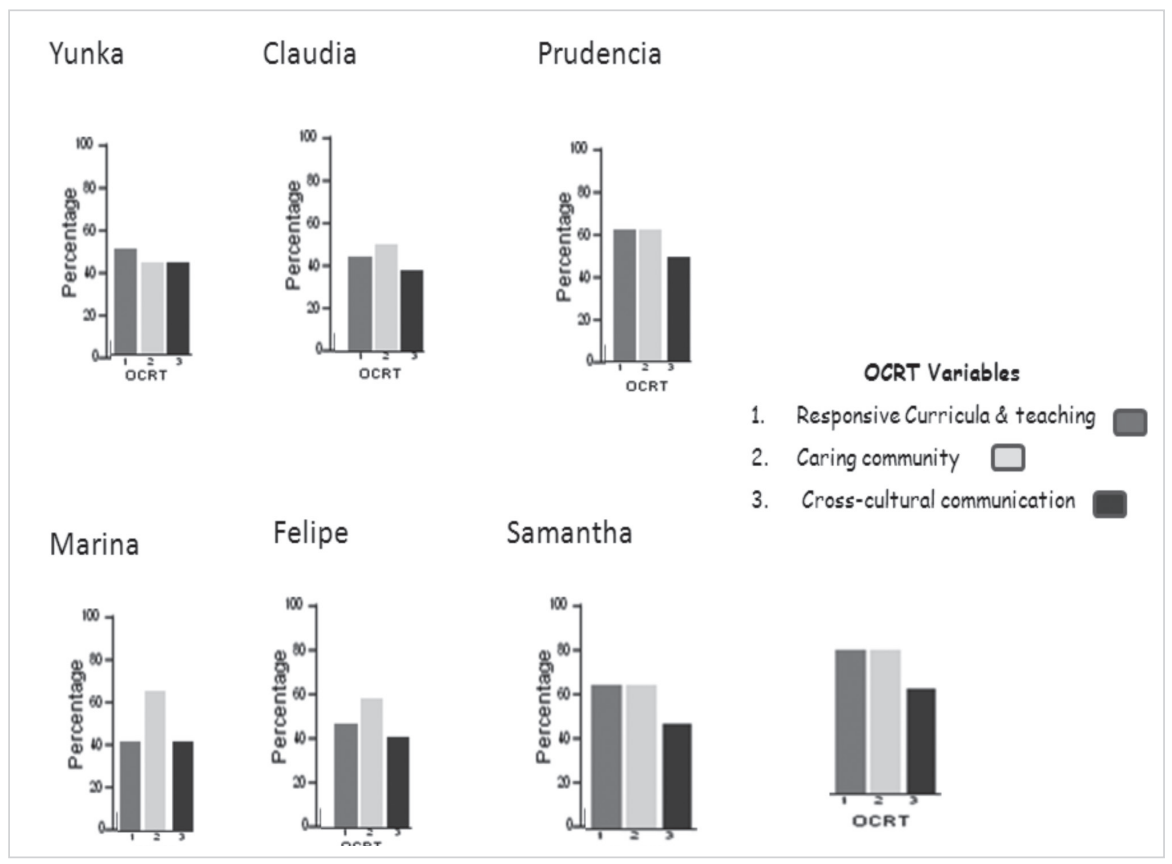

Figure1. Orientation to culturally responsive teaching 
The primary reading of the above figure suggested that culturally responsive skills development competence is not a linear upward process. All participants scored below $60 \%$ in cross-cultural communication skills. Yunka, Claudia, Marina and Felipe also scored below $60 \%$ in responsive curriculum and teaching practices while Samantha and Prudencia scored above $60 \%$ and below $70 \%$, as indicated in Figure \#1. Moreover, Yunka, Claudia and Felipe scored below $60 \%$ in caring community skills, while Marina, Samantha and Prudencia scored above $60 \%$ and below $70 \%$. In other words, the 6 participants scored below $70 \%$ in responsive curriculum and teaching practices, caring community and crosscultural communication skills. This suggested the importance of making more intercultural learning and teaching training opportunities available to them in order to further assist them in enhancing their curriculum transformation and culturallyresponsive leadership skills. Furthermore, the fact that all 6 participants scored below $60 \%$ in crosscultural communication skills might potentially hinder their abilities to transform ELL classroom curriculums from being essentially Euro/Westerncentric to fully culturally responsive ones.

\section{AddressingResearch Question \#1}

The first research question was: in a subtractive bilingualism setting, how will NNES elementary ELL teachers implement culturallyresponsive teaching tenets and principles when teaching elementary ELL classrooms?

Two different patterns can be highlighted here. Four participants limited themselves in performing additive curriculum transformation. Felipe, Yunka, Marina and Claudia agreed that the official accent on teachers' accountability limit their creativity to perform some sorts of curriculum transformation. Data from classroom observations confirmed the absence of innovative instructional strategies, teacherhome connections and communications in Felipe, Yunka, Marina and Claudia's practices.
In contrast, Samantha and Prudencia demonstrated an opposite approach to teaching elementary ELL curriculums (English, mathematics, science and social sciences) to elementary ELL students. Both participants claimed that limiting themselves to the "official cannon or practice" was a waste of human capital resources. Samantha's vision focuses on students becoming independent thinkers and explorers, and their able to approach the many challenges of a pluralistic society with confidence and thoughtfulness. Her teaching and classroom practices have more than one focal point: the move beyond her classroom. She once voiced her ideal school as: "one in which my colleagues and I are committed to move beyond classrooms".

Despite some institutional reluctance or open opposition to their "exotic" teaching in ELL classrooms, Prudencia and Samantha felt like they were compelled to do that extra work to connect to their students and families in order to foster higher intercultural learning experience. The following segment explains some of the basic features of Samantha and Prudencia's culturallyresponsive practices.

\section{Instructional Conversation}

Instructional conversation was the first culturally-responsive practice that Samantha and Prudencia used in their daily teaching practices. This instructional strategy is highly recommended for use with culturally and linguistically diverse learners. It is a reflexive conversational and educative discussion in which ideas are explored rather than answers to teachers' test questions provided and evaluated. It promotes critical thinking, students' engagement and responsibilities (Cazden, 1988).

Naturally, Samantha and Prudencia's instructional conversation practices were studentcentered, where students shared and negotiated 
content mostly from social sciences. For example, Samantha and Prudencia provided their students with ample opportunities to share what they know about the history of their parents' home countries, culture(s) and traditions on a bimonthly or quarterly basis. With the help of their parents, ELL students prepared a very brief talk and practiced it with the teacher before presenting it to either a small group of peers $(3-5)$ or the whole class. Some brief talks were performed using a poetic format.

By doing so, both teachers (Samantha and Prudencia) gave their students voices, even if these were insurgent ones. All elementary ELL students from different cultural and linguistic backgrounds learned from each other (peer learning). Data from classroom observations also demonstrated that instructional conversations promoted oral fluency in English and indirectly helped children to learn more about their own heritage cultures while learning social sciences content. QUAL analysis suggested that Samantha and Prudencia's instructional conversations were effective peer-learning, trust-building activities which potentially increased their ELL students' learning retention rates. According to the Lalley and Miller (2007), peer-learning has been accredited as one of the best instructional strategies aimed at increasing students' learning retention rates.

\section{Generative and School of Contrast Instruction}

The generative and school of contrast instruction were the second frequent culturally responsive strategies that Samantha and Prudencia often used in their respective elementary ELL classrooms. Data gathered through classroom observations demonstrated that the generative and school of contrast have been used as curriculum and instructional strategies to transform the official ELL classroom curriculums through the aforementioned research subjects. For example, Samantha created her supplemental read-aloud scripts based on her students' writings. The generative instructional method we observed in Prudencia's classroom worked as described below. The teacher asked ELL students from different cultural and linguistic backgrounds to write paragraphs or pages about their native cultures or countries, what they valued and appreciated the most. Based on the students' writing drafts, the teacher corrected them in order to create several reading materials for her reading class to be used throughout the school year.

To be fair to all students, she planned to use all students' writings during a period of time, after discussing each reading with the whole class. According to some scholars (Banks, 2008; Ladson-Billings, 1995 and McIntosh, 2000), asking students from each cultural background to provide detailed insights not included in the curriculum, or bringing parents or experts from each culture as guest speakers, enhance students' learning and retention, motivation, cultural awareness and cultural knowledge.

Another culturally-embedded curriculum transformation strategy often used by Prudencia to enhance her students' learning is the school of contrast described in Pipher (2002) as an effective intercultural learning strategy. Here, the teacher asked each elementary ELL student to search and present some cultural characteristics of another ethnic group, instead of asking participants to write about their own cultures. The teacher scaffolded elementary ELL students' search processes and writing to help them discover the visible and invisible aspects of their peers' cultures. Writing drafts were corrected by the teacher in order to be considered as readingwriting resources for teaching. Creativity in the production of culturally-embedded resources for elementary ELL classrooms depends on the 
teacher's cultural and cognitive capacities to learn about her students' cultures and to be highly responsive to others.

\section{Jurisprudential Teaching}

Jurisprudential teaching (instructional strategy aimed at building awareness on issues related to social justice, race, discrimination, segregation, etc.) was the third frequent culturallyresponsive strategy that Felipe and Prudencia often used in their respective elementary ELL classrooms. It was implemented especially to make ELL students aware of the characteristics of their current learning and life contexts. Teachers presented videos (for example: El Norte) related to equity, social justice and ethic issues and the history of civil right movements. Even though, the jurisprudential teaching inquiry is suitable for secondary students, Felipe and Prudencia used this instructional inquiry based on casestudy method to introduce their students to the challenges faced by new immigrant families today in the United States of America. The case studies presented arguments, facts, situations or events and the teachers asked the students to think of the issues as they see them on the video, and to request more information from the teacher. After watching the video, a class discussion led by the teachers took place on issues related to equity, social justice, moral and ethical values, and new immigrant situations within pluralistic communities.

The jurisprudential instructional method applied in Felipe and Prudencia's elementary ELL classrooms focused on building multicultural awareness among learners. Based on their families' historical hardships when moving to the United States of America, Felipe thought that it was important to start building ELL students' cultural awareness and the sense of social justice, equality and equity at early age.

\section{Learning Through Play}

Prudencia and Samantha agreed that one of the most common elements of childhood across cultures is play. They recognized the importance of play in the lives of young children and make use of play as a way of learning and promoting cultural diversity. Both Prudencia and Samantha, referred to various educational scholars (York, 1992; Cliff, 1990; Lederberg, Chapin, Rosenblatt, $E$ LoweVandell, 1986) who stressed the importance of play and games in multiracial and multicultural classrooms. During the first in-depth interview, Prudencia expressed her interest in exploring the relationship between plays/games and diversity as suggested by Rettig (1995).

Samantha's preferred play type was role playing. During a follow-up interview, researchers asked her why she was interested in using role playing as instructional strategy to foster meaningful learning experiences and cultural diversity. Samantha replied that:

\section{"my interest in applying role playing play arose after reading the controversy around whether children from low income homes have deficits in imaginative and dramatic play when I was in graduate school."}

The central issue of controversy was whether children from low socioeconomic, non-Western homes have underdeveloped imaginative play skills (Johnson, Christie, \& Yawkey, 1987). She preferred to move beyond the controversy in order to truly use play as an instructional strategy aimed at teaching her elementary ELL students. At the same time, she was giving her students the opportunity to improve their oral fluency and fostering their confidence to speak in public. Elementary ELL students in Samantha's classroom performed role-plays based on several reading topics such as the civil rights movement, the life of Cesar Chavez, the lion dance ( type of Chinese dance), etc. 
Fostering learning through play includes: a) teachers' knowledge to get to know their students' cultural backgrounds (Jalongo, 1992) and stressing how important it is to be aware of communication styles of the children by learning the communication styles in the home; b) the teachers' ability to bring the outside world into the classroom (Jalongo, 1992) through the use of materials and activities; c) the teachers' ability to use literature to enrich play and an understanding of cultural pluralism (free of biases and negative stereotypes); d) initial adoption of a multicultural approach of pop culture to connect to children's cultural heritage.

\section{Addressing Research Question \#2}

The second research question was: What is/ are the optimal culturally responsive leadership profile(s) which helped research participants to perform ELL curriculums' transformation in a predominantly subtractive bilingual setting?

Observational data suggested that in a multicultural classroom, teacher leadership style is one of the factors that influences overall elementary ELL students' learning. Some of the participants were not aware of their teaching leadership styles until the authors shared the emerging themes and the basic profile of culturally-responsive NNES English teachers which emerged from the qualitative data analysis.

Comparative analysis of classroom observations and interviews revealed that Marina, Claudia, Yunka and Felipe, who considered themselves as bilingual-bicultural individuals, saw themselves as being as good as their NES colleagues by keeping the ship afloat, expressed concern about institutional accountability, adopted a reward system and the traditional approach of communicating with elementary ELL parents, used classroom interaction and management patterns, and implemented additive multicultural curriculum transformation strategies. This all strongly suggested that their teaching styles were influenced by transactional leadership styles. In fact, teachers who displayed a transactional leadership style were more concerned about the status quo. As transactional leaders, generally the teachers did not look ahead strategically (Bass $\mathcal{E}$ Riggio, 2006) in order to move toward advanced stages of multicultural curriculum transformation aimed at ensuring quality or exemplary instruction for elementary ELL students. Instead, the teachers were worried about making sure everything worked smoothly every day.

Prudencia, who considered herself as a multilingual-multicultural individual, displayed many qualities which suggested that her teaching was influenced by a transformational leadership style: a deep commitment to her elementary ELL students' cultural values, open communication, openness to new ways of doing things, modeling learning, contagious enthusiasm, ability to inspire her students and parents, ability to set higher academic and personal expectations for her students, nurturing skills, challenging of the status quo and commitment to promoting structural school environment and curriculum changes to accommodate her students from culturally and linguistically different backgrounds in a predominantly white school district. In fact, teachers who displayed the above qualities encompass Bass and Riggio's (2006) transformational leadership in nature.

Samantha, who also considered herself as multilingual-multicultural individual, was the only research participant who identified herself as a servant teacher during the first in-depth interview. She clearly stated that:

\section{"Serving my students and helping my school to be highly responsive to differentiated teaching is crucial for me".}

Furthermore, Samantha's social action and personal multicultural curriculum transformation and determination to promote radical changes in her students' direct world outside the classroom/ 
school all suggested that her teacher leadership was influenced by a servant leadership style. The table below summarizes the emerging culturally responsive leadership profile of the 6 participants.

Table 4.1: The Emerging Culturally Responsive Leadership Profile of NNES ELL Elementary Teachers

\begin{tabular}{|c|c|c|c|}
\hline $\begin{array}{l}\text { Teaching } \\
\text { Performance } \\
\text { Standards }\end{array}$ & $\begin{array}{c}\text { Teacher Self-ranked } \\
\text { Cultural Identity } \\
\text { Status }\end{array}$ & Leadership Styles & $\begin{array}{l}\text { Multicultural Curriculum } \\
\text { Transformation Stages } \\
\text { (Bank \& Mclntosh) }\end{array}$ \\
\hline Good & Bilingual-bicultural & Transactional Leadership & $\begin{array}{l}\text { Additive multicultural } \\
\text { curriculum transformation } \\
\text { practices }\end{array}$ \\
\hline Effective & $\begin{array}{l}\text { Multilingual- } \\
\text { multicultural }\end{array}$ & Transformative Leadership & $\begin{array}{l}\text { Integration/structural } \\
\text { multicultural curriculum } \\
\text { transformation practices }\end{array}$ \\
\hline Highly Effective & $\begin{array}{l}\text { Multilingual - } \\
\text { multicultural }\end{array}$ & Servant leadership & $\begin{array}{l}\text { Social action and personal } \\
\text { multicultural curriculum } \\
\text { transformation practices }\end{array}$ \\
\hline
\end{tabular}

It is important to highlight that our data analysis did not suggest a direct casual relationship between teaching performance standards and multicultural curriculum transformation stages. However, qualitative findings suggested an intrinsic relationship between NNES elementary ELL teachers, self-perception of their cultural identity, leadership style and their ability to perform multicultural curriculum transformation within traditional elementary ELL classrooms in a specific ESL context in the US. In other words, these qualitative findings cannot be generalized to all NNES elementary ELL teachers in ESL and/ or EFL contexts.

\section{Conclusions \& Implications for NNES Elementary ELL Teacher Education in an ESL Context}

This paper explored NNES elementary ELL teachers' culturally-responsive leadership profile in a specific ESL context in a north-central school district of the United States of America. Comparative data analysis suggested that there was no causal relationship between NNES' elementary ELL teachers' culturally responsive leadership styles and their abilities to perform multicultural curriculum transformation.

According to McIntosh (2000), teachers should learn how to perform the five steps of curriculum transformation in order to effective transform a gender-centric and ethno-centric curriculum to a multicultural one. Moreover, graphical data, as discussed above, pointed out that all 6 participants scored below $70 \%$ in responsive curricula and teaching practices, caring community and cross-cultural communication skills, which suggested the importance of making more intercultural learning and teaching training opportunities available to them in order to further assist them in enhancing their curriculum transformation and culturally responsive leadership skills.

Despite practical constraints, data analysis highlighted how some participants where moving forward in the process of adopting culturally responsive instructional strategies such as instructional conversations, generative and school 
of contract, jurisprudential teaching and learning through play, which were essentially inclusive and gave each student voice to tell his or her own story within the elementary ELL classrooms. In the same vein, findings suggested that the adoption of those culturally responsive instructional strategies depended upon each participant's self-ranked cultural identity status and leadership style. Four NNES elementary ELL teachers who displayed transactional leadership style implemented the additive strategy of multicultural curriculum transformation. One NNES elementary teacher who displayed the transformative leadership style adopted the integration or structural strategy of multicultural curriculum transformation. Another NNES elementary teacher who displayed the servant leadership style adopted the social action and personal strategy of multicultural curriculum transformation suggested by Banks (1993) and McIntosh (2000).

Theoretically, we contended that any culturally responsive instructional strategy was transformative in nature and should be considered as vector of a pluralistic and multicultural society that works well for everyone, without implicitly or explicitly highlighting the history, culture and language of any ethnic group (especially the dominant ethnic group) as superior to others through textbooks or the massive use of teachers from the hegemonic group (Spring, 2007). Transformation of elementary ELL classroom curriculums from gender-centric and Euro/ Western-centric to pluralistic and multicultural ones in the global area, is the starting point of restoring the human capacity to feel close and connected to all other human beings. Feeling close and connected does not mean the suppression of differences. It does mean that in a subtractive bilingualism, elementary ELL students must not only learn the history, stories, languages and cultures of the hegemonic group, but also strength their own linguistic and cultural heritage(s). Here is where NNES ELL teachers who are cultural insiders or insiders of at least two cultural reference groups must play a crucial role in designing multicultural ELL curriculums and culturally responsive instructional techniques.

A critical reading of research results discussed in the previous section suggested the critical need of preparing culturally responsive NNES ELL teachers for elementary ELL classrooms in the United States of America. Based on the above findings, we might argue in favor of pluralistic and multicultural settings, in which NNES elementary teachers are deeply involved in a lifelong process of becoming and remaining cultural insiders or at least intimately familiar with their primary cultural reference groups (heritage $\mathcal{E}$ host).

Certainly, training culturally-responsive NNES elementary ELL teachers is a complex process which requires teamed and collaborative endeavors. We anticipate that this process is even complex in EFL settings, where preservice EFL teachers have limited exposure and interaction with the target language and culture. In an ESL context, ELL teacher educators must acknowledge the difficulty in helping prospective NNES ELL pre-service teachers to change deeply-rooted and relatively unconscious learning habits and acquired beliefs, values and schemata.

Enhancing future NNES elementary ELL preservice teachers' culturally responsive leadership and multicultural curriculum transformation skills in an ESL context is very important to radically change the historical and widespread Euro/ Western-centric ELL curriculum design trend. It is a necessary culturally-responsive teacher education actions needed to strengthen culturallyresponsive ELL curriculum and instructional designers' innovation, creativity and autonomy.

\section{References}

Abdal-Haqq, Ismat (1994). Constructivism in teacher education: considerations for those who would linkpractice to theory. ERIC Clearinghouse on Teaching and Teacher Education. Retrieved on November 20, 2008 from http://www.ericdigests. org/1999-3/theory.htm 
Baker, C. (2011). Foundations of bilingual education and bilingualism. $5^{\text {th }}$ Edition. Bristol, UK: Multilingual Matters

Banks, J.A. (1993). Approaches to multicultural curriculum reform. In Banks, J. and Banks C. (Eds), Multicultural education: Issues and perspectives. Allyn \& Bacon

Banks, J.A. (1998). The lives and values of researchers: Implications for educating citizens in amulticultural society. Educational Researcher 27 (7) 4 - 17.

Banks, J.A (2001) Cultural diversity and education: Foundations, curriculum, and teaching. Upper Saddle River NJ: Allyn and Bacon.

Banks, J.A. (2008) Teaching strategies for ethnic studies (8th Edition). Upper Saddle River NJ: Pearson Education.

Banks, J.A. (2008). An introduction to multicultural education (4th Edition). Upper Saddle River NJ: Pearson Education.

Bartunek, J.M \& Moch, K.M. (1987). First-order, secondorder, and third-order change andorganization development interventions: A cognitive approach. Journal of Applied Behavioral Science 23(4) 483-500 DOI 10.1177/002188638702300404

Bass, B. \& Riggio, R.E. (2006). Transformational Leadership. Hillsdale, NJ: Lawrence Erlbaum Associates

Braine, G. (1999). Non - native English Educators in English language teaching. Mahwah, N.J: Lawrence Erlbaum Associates.

Braine, G. \& Ling, C.Y. (2007). The Attitudes of University Students towards Non native Speakers-English Teachers in Hong Kong. RELC Journal. 38 (3) 257 -277 .

Brown, D. (2006). Principles of language learning and teaching. 5ht Edition. Englewood Cliffs, NJ: Pearson ESL

Canagarajah, A.S. (1999). Resisting linguistic imperialism in English teaching. New York, NY: Oxford University Press.

Canagarajah, A.S. (2007). Lingua franca English, multilingual communities, and language acquisition. Modern Language Journal, 91 (5) 921-937

Cazden, C. (1988). Classroom discourse: The language of teaching and learning. Portsmouth, $\mathrm{NH}$ : Heinemann.

Charmaz, K. (2010). Constructing grounded theory. A practical guide through qualitative analysis. $2^{\text {nd }}$ reprint. Thousand Oaks, CA: Sage Publications
Chion-Kenney, L. (1994). Weaving real-life images and experiences into Native education. R\&D Preview 9 (1) 4-5.

Cliff, M. (1990). Navajo games. American Indian Culture and Research Journal 14, 1-81.

Creswell, W., J. (2012). Qualitative inquiry and research design: choosing among five approaches. $3^{\text {rd }}$ Edition. Thousand Oaks, CA: Sage Publications

Dickerson, S. (1993). The blind men (and women) and the elephant. A case for a comprehensive multicultural education program at the Cambridge Rindge and Latin School. In Perry, T.A \& Fraser, J.W. (Eds.), Freedom's plow. Teaching in the multicultural classroom. London, UK: Routledge.

Ekiaka Nzai, V. \& Reeves, J. (2010). Bilingual-bicultural teachers' cultural competence. Development blueprint in predominantly subtractive bilingualism settings: Insights from research literature. Tabe Journal 12(1\&2); 1-24

Edwards, K. (2003). Increasing cultural competence and decreasing disparities in Health. Journal of cultural diversity 10 (4) 111 - 112

Freire, P. (1973). Education for critical consciousness. New York, N.Y: Seaburg.

Gay, G. (2000). Culturally responsive teaching: theory, research and practice. New York, N.Y: Teachers College Press.

Gay, G. (2002). Preparing for culturally responsive teaching. Journal of teacher education. 53(2) 106 $-116$.

Goldenberg, C. \& Gallimore, R. (1991). Changing teaching takes more than a one-shot workshop. Educational Leadership. 49 (3) 69-72.

Greenleaf, R. \& Spears, L.C. (Ed). Servant Leadership: A Journey into the Nature of Legitimate Power and Greatness. Peabody, MA: Paulist Press.

Gruwell, Erin. (2007). Teach with your heart: lessons I learned from the freedom writers. New York, N.Y: Broadway Books.

Haberman, M. (1996). Selecting and preparing culturally competent teachers for Urban Schools. In Sikula, J. (Ed.), Handbook of research on teacher education, (2nd Edition), New York: Simon \& Schuster Macmillan.

Hilliard, A. (1991-1992). Why we must pluralize the curriculum. Educational Leadership V. 49(4) 12-16.

Jalongo, R. (1992). A resource for multicultural education. In. Vold E.B (Ed). Multicultural education in early 
childhood classrooms. NEA early childhood education series $52-56$.

Johnson, E., Christie, F. \& Yawkey, D. (1987). Play and early childhood development. Glenview, IL: Scott, Foresman and Co.

Koppelman, K., L., (2008). Understanding human differences: multicultural education for a diverse America (2nd Edition). Upper Saddle River, NJ: Pearson Education.

Kumashiro, K. (2004). Against common sense: teaching and learning toward social justice. NY: Routledge Falmer

Kumashiro, K. \& Bic. Ngo, Eds. (2007). Six lenses for antioppressive education: partial stories, improbable conversations. NY: Peter Lang

Ladson - Billings, Gloria (1995). Toward a theory of culturally relevant pedagogy. American Educational Research Journal 32, 465-491.

Lalley, J.P. and Miller, R.H. (2007). Does It Point Teachers in the Right Direction. Education, 128 (1) 64-79

Lederberg, A., Chapin, S., Rosenblatt, V. \& Lowe-Vandell, D. (1986). Ethnic, gender, and age preferences among deaf and hearing preschool peers. Child Development. 57 (2) 375 - 385.

Leech, L.N. \& Onwuegbuzie, J.A. (2007). A typology of mixed methods research designs, Retrieved from http://blogskin.gigfa.com/up1/1394475902.pdf

Llurda, E. (2005). Non-Native Language Teachers: Perceptions, Challenges and Contributions to the Profession. New York, NY: Springer

Mclntosh, P. (2000). Interactive phases of personal and curricular revision with regard to race. In G. Shin and P.Gorski (Eds). Multicultural resource series: Professional development for educators. National Education Association.

Middleton, J. Ernest, Mason, E., Stilwell, W. \& Parker, W. (1988). A model of recruitment and retention of minority students in teacher preparation programs. Journal of Teacher Education 39, 14 - 18.

Nebraska StatePaper, (2009). Nebraska among 13 states with at least 200 percent growth in English language learners. Retrieved from http:// nebraska.statepaper.com/vnews/display.v/ ART/2009/01/07/4964ed90a1326

Nieto, S. \& Bode P.(2008). Affirming Diversity: The sociocultural context of multicultural education (5th Edition). Upper Saddle River, N.J: Pearson Education.

Noddings, N. (1999).'Two concepts of caring', Philosophy of Education,http://www.ed.uiuc.edu/EPS/PESyearbook/1999/noddings.asp. Retrieved August 2, 2008.

Onwuegbuzie, A.J., Johnson, R.B (2004). Mixed method and mixed model research. In: Johnson, R.B., Christensen,L.B. (eds.) Educational Research: Quantitative, Qualitative, and Mixed Approaches, pp. 408-431. Needham Heights, MA: Allyn and Bacon

Patton, M.Q. (1990). Qualitative evaluation and research methods (2nd ed.). Newbury Park, CA: Sage

Pipher, M. (2002). The middle of everywhere: helping refugees enter the American community. Orlando, FL: Harcourt Press.

Reid, J., Forrestal, P. \& Cook, J. (1989). Small group learning through group investigation. New York, N.Y: Teachers College Press.

Rettig, M. (1995). Play and cultural diversity. The Journal of Educational Issue of Language Minority Students $151-8$

Rothenberg, C.\& Fisher, D. (2009); Teaching English Language Learners: A Differentiated Approach. Upper Saddle River, N.J: Prentice Hall

Soltero, W.S.(2004) Dual Language: Teaching and Learning in Two Languages. Boston, MA: Allyn \& Bacon,Inc.

Scherer, M. (1991-1992). School snapshot: Focus on African-American culture. Educational Leadership. 49 (4) 17-19.

Spears, J. D., Oliver, J. P., \& Maes, S. C. (1990). Accommodating change and diversity: Multicultural practices in rural schools. A report of the Ford Western Taskforce. Lawrence, KS: Kansas State University.

Spring, J. (2007). Deculturalization and the struggle for equality (5th Edition). Columbus, OH: McGraw-Hill.

Villegas, A.M. (1991). Culturally responsive teaching for the 1990s and beyond. Washington, D.C.: American Association of Colleges for Teacher Education.

York, S. (1992). Developing roots and wings: A trainer's guide to affirming culture in early childhood programs. Rainier, MD: Gryphon House. 


\section{Appendix 1: Questionnaire}

Title: Orientation to Culturally Responsive Teaching Questionnaire (OCRTQ)

Date:

Instructions: please react to the following statements. Be honest when reacting to each item. I encourage you to react to all items and provide rationale, examples or description when needed. The questionnaire' scale is as described below:

$$
\text { strongly agree }=3 \quad \text { agree }=2 \text { disagree }=1 \quad \text { strongly disagree }=0
$$

1. In my daily teaching practicum, I have developed a genuine understanding of an ELL classroom as a community of learners. strongly agree agree disagree strongly disagree

Describe:

2. In my daily teaching practicum, I consider myself a leader who serves, cares and nurtures my pupils strongly agree agree disagree strongly disagree

3. I socialize with my students and their families outside classroom/School strongly agree agree disagree strongly disagree

4. I spend much of my free time visiting, communicating and learning cultural features of my diverse ELL students strongly agree agree disagree strongly disagree

Please, provide some examples:

5. My students and their families consider me as role-model, coach, resource person, and counselor. Etc. strongly agree agree disagree strongly disagree

6. To me, serving diverse ELL students and helping them to succeed as global citizen is crucial. I do not expect any reward for any teaching practicum that implies actions on behalf of my ELL students' needs

strongly agree agree disagree strongly disagree

7. I understand all my ELL students' cultural background, and I often use elements from their cultures and traditions to prompt my teaching strategies or to better connect with them in order to foster meaningful learning experiences

strongly agree agree disagree strongly disagree

8. I understand my ELL students' cultural communicative styles system strongly agree agree disagree strongly disagree

\section{Provide some examples:}

9. I use my ELL students' cultural communicative styles system to connect with them and their parents strongly agree agree disagree strongly disagree

10. I use my students' cultural communicative styles, pop cultures, traditions and values to prompt culturally responsive teaching practices within my ELL classroom

strongly agree agree disagree strongly disagree

11. As non-native or native English-speaking elementary ELL teacher, I have developed my own strategies to overcome cognitive dissonance $\left.{ }^{(* *}\right)$ effects and cultural distance within a diverse ELL classroom.

strongly agree agree disagree strongly disagree 


\section{Provide some examples:}

12. I have developed genuine culturally responsive classroom management strategies to ensure a fun learning setting. Also, I am aware of how the lack of culturally responsive classroom strategies, appraisal and motivational techniques affect my ELL students' performance in some subject matters like English, mathematics, science and social sciences. Provide some examples

strongly agree agree disagree strongly disagree

Describe:

${ }^{* \star *}$ Cognitive dissonance: how people respond to information that does not coincide with their current understandings or beliefs

\section{THE AUTHORS}

DR. VALENTIN EKIAKA NZAI holds an Ed.D from University of Nebraska-Lincoln. He is a multilingual-multicultural Assistant Professor of Teacher \& Bilingual at Texas A\&M University-Kingsville. His research focuses on cyberlearning technologies and pedagogy, digital game -based curriculums \& 3D virtual learning environments, culturally responsive and anti-oppressive education, interracial marriages, ethnic media and cultural identity re-constitution.

DR. PATRICIA GómEZ holds an Ed.D from Texas A\&M University at Corpus Christi. She is an Assistant Professor of Teacher \& Bilingual and Doctorate Coordinator at Texas A\&M University-Kingsville. Her research focuses on dual-language instruction and dual-language teacher education preparation.

DR. CONCEPCIÓN REYNA holds an Ed.D from Texas A\&M University-Kingsville and just graduated with a doctorate in Bilingual Education from Texas A\&M University-Kingsville (TAMUK). She is currently working as an Instructor at TAMUK Language Learning Center. Her research focuses on Mexican American children vocabulary acquisition and innovative teaching strategies for digital native students.

DR. KANG-FAN JEN holds an Ed.D from Texas A\&M University-Kingsville, just graduated with a doctorate in Bilingual Education from Texas A\&M University-Kingsville (TAMUK). He is currently working as Instructor at a Taiwanese University in Taichung, Taiwan. His research interests focus of multimedia technologies for multilevel ESL classrooms and self-designed 3D virtual world learning environments for English classrooms. 